\title{
Analysis of a contact zone in the Forficula auricularia L. (Dermaptera: Forficulidae) species complex in the Pyrenean Mountains
}

\author{
S. GUILLET $\dagger^{*}$, A. GUILLER $\uparrow$, J. DEUNFF $\ddagger$ \& M. VANCASSEL $\dagger$ \\ †UMR CNRS 6553, Université dé Rennes I, Bat. 14, Campus de Beaulieu, Avenue du Général Leclerc, \\ 35042 Rennes cedex, France, \$UMR CNRS 6553, Parasitologie Pharmaceutique, Université de Rennes, Avenue du \\ Pr. Léon Bernard, 35043 Rennes cedex, France
}

\begin{abstract}
The taxon Forficula auricularia L. (Dermaptera: Forficulidae) is a complex of two sibling species that differ in life history (number of clutches per year and imaginal diapause) and that have diverged at the molecular level. The study of a contact zone in the Pyrenean Mountains, using the PCR-RFLP method on two mitochondrial regions (the 16S rRNA and the Cytochrome Oxidase intergenic region), revealed the coexistence of the sibling species at intermediate altitude $(1200 \mathrm{~m})$ whereas at lower and higher altitudes only one species was found. An allozyme study, conducted simultaneously and based on four polymorphic loci (PGI1, AAT1, Est-P1 and Est-P2), showed no sign of nuclear introgression. The apparent lack of hybridization in the field is consistent with a postzygotic barrier observed in the laboratory (a nearly complete failure to produce $F_{1}$ hybrids). This contact zone is probably a sympatric zone between two genetically differentiated species.
\end{abstract}

Keywords: allozymes, Forficula auricularia, mtDNA, sibling species, sympatry.

\section{Introduction}

Contact zones are of great interest for evolutionary genetic and biological studies. They offer excellent opportunities to study many aspects of genetic divergence and speciation, gene flow and introgression, natural selection and adaptation (Barton \& Hewitt, 1985, 1989; Arnold, 1992; Harrison, 1993; Vasquez et al., 1994). Hybrid zones are not easily accommodated within the framework of the 'biological species concept' in which the criterion for species status is reproductive or genetic isolation. Furthermore, for most taxa, the 'acid test' for biological species status, whether the populations retain separate identities in sympatry, has not been carried out in the wild (Harrison, 1993; Avise, 1994; Rieseberg, 1998).

The taxon Forficula auricularia was recently identified as a complex of at least two sibling species differing at the molecular level, through mitochondrial divergence in the COI/COII intergenic region and in the 16S rRNA gene, and in their reproductive life histories (Wirth et al., 1998; Guillet et al. 2000). One reproductive strategy, characterizing populations living in colder

*Correspondence. E-mail: stephanie.guillet@univ-rennes1.fr climates (species A), consists of having one reproductive cycle a year, ending with a long gregarious phase (Vancassel, 1984). The second strategy, seen in populations living under temperate and oceanic climates (species B), consists of two successive reproductive cycles per female, yielding two cohorts per year, with a relatively early dispersal of the first larval cohort (Weyrauch, 1929; Beall, 1932; Lamb \& Wellington, 1975). A nearly complete failure to produce $F_{1}$ hybrids was observed in the laboratory when individuals of these two sibling species were paired (Wirth et al., 1998). To date, however, the existence of total reproductive isolation has not been tested in the wild.

In the Pyrenean mountains (near the French-Spanish border), the sibling species are found at different altitudes. The first species (A, one brood per year) is found in the Alpine zone above $1300 \mathrm{~m}$. The second species ( $\mathrm{B}$, characterized by an imaginal diapause and two clutches per year) has been observed in lucern fields up to $1100 \mathrm{~m}$. Because recent forestry has destroyed the ecological barrier existing between those two habitats, expansion and subsequently contact between populations of the sibling species could have occurred.

Several studies of contact zones have employed different markers simultaneously (Harrison et al., 
1987; Nelson et al. 1987; Rand \& Harrison, 1989; Szymura \& Barton, 1991; Hewitt, 1993; Vasquez et al., 1994). Indeed, comparisons of cytoplasmic (mtDNA) and nuclear (allozyme) markers can give considerable insight into the dynamics of genetic introgression (Marchant, 1988; Vasquez et al., 1994; Oldroyd et al., 1995). These markers are valuable for assessing the magnitude and pattern of genetic exchange among related forms, as sibling species, and thereby can contribute to an understanding of the intensity and nature of reproductive isolating barriers (Avise, 1994).

The Forficula auricularia suspected contact zone was sampled along an elevation transect. Information from nuclear (allozyme) and cytoplasmic (mtDNA) markers was combined to demonstrate the coexistence of the sibling species in the same habitat, and to document the extent of reproductive isolation in the wild. Initially, mtDNA was used to identify different haplotypes characteristic of the sibling species, to describe their distribution along the transect and to support inferences about reproductive isolation. Mitochondrial DNA is a separate genetic system that is considered to be strictly maternally inherited. It has often been used as a probe of interspecific gene flow (Ferris et al., 1983; Avise \& Saunders, 1984; Spolsky \& Uzzel, 1984). Indeed, mitochondrial variants may introgress more readily than alleles for nuclear genes (Harrison et al., 1987). Furthermore, evidence of hybridization will remain in a population as long as the matrilineal mtDNA survives (Lehman et al., 1991). But, because of its maternal inheritance, mtDNA cannot, on its own, confirm or refute a hypothesis of hybridization. In addition, therefore, these populations were examined for allozyme variation. Indeed, patterns of variation observed in hybrid zones often reveal concordant transitions for the different genetic characters being examined (Bert \& Harrison, 1988; Baker et al., 1989; Barton \& Hewitt, 1989; Szymura \& Barton, 1991); these clines may be maintained by a balance between dispersal and selection against hybrids, or by hybrid superiority in areas of ecological transition (Barton \& Hewitt, 1985).

\section{Materials and methods}

\section{Samples}

Five neighbouring samples of Forficula auricularia were collected in the Pyrenean mountains (Mijanes, Haute Vallée de l'Aude, $42^{\circ} 44^{\prime} \mathrm{N}, 2^{\circ} 3^{\prime} \mathrm{E}$ ) in August 1996 at 900 , $1100,1200,1300$ and $1500 \mathrm{~m}$, respectively. Adult earwigs were collected using traps described by Lamb \& Wellington (1974). Thirty individuals per locality were assayed, except at $1200 \mathrm{~m}$ (22 ind.).

\section{DNA isolation, amplification and restriction}

Total DNA was extracted from the head and thorax of each individual by standard SDS/proteinase K digestion followed by phenol/chloroform extraction and ethanol precipitation (Sambrook et al., 1989). Two mitochondrial regions were amplified by PCR: a portion of the $16 \mathrm{~S}$ rRNA region (544 bp) and the $\mathrm{COI} / \mathrm{COII}$ intergenic region (627 bp) (Guillet et al. 2000). PCR products were digested with seven endonucleases (HaeIII, MboI, EcoRI, HpaII, CfoI, HinfI and MspI) and DNA restriction fragments were separated on a $3 \%$ agarose gel and stained with ethidium bromide, in order to reveal polymorphism.

\section{Protein electrophoresis}

Abdomens were homogenized in $200 \mu \mathrm{L}$ of stabilizing buffer and centrifuged at 12000 r.p.m. for 10 minutes in order to remove large cellular debris. The supernatant was collected and stored at $-80^{\circ} \mathrm{C}$ before use. Protein extracts were analysed by horizontal starch gel electrophoresis (Second \& Trouslot, 1980). In order to discover polymorphic loci, material from several individuals from the two most distant samples (900 and $1500 \mathrm{~m}$ ) were studied for 37 enzyme systems (list available upon request). On the basis of these data, loci that appeared to show distinct alleles across the zone were selected.

\section{Data analysis}

\section{Restriction patterns}

For each endonuclease that revealed restriction polymorphism, each variant pattern was assigned an upper case letter designation (A, B...). Then, each individual was identified as belonging to one of the sibling species using mtDNA restriction-fragment patterns (Guillet et al., 2000).

\section{Electrophoretic data}

Genetic variability measures (allele frequencies and heterozygosity estimates) were calculated using BIOsYs-1, release1.7 (Swofford \& Selander, 1989). The genetic structure within and between populations was analysed with the help of two software programs: FSTAT v. 1.2 (Goudet, 1995), which performs Weir \& Cockerham's (1984) modification of Wright's (1965) F-statistics, and GENEPOP V. 1.2 (Raymond \& Rousset, 1995), which analyses the fit of the data to Hardy-Weinberg expectations. 


\section{Results}

\section{MtDNA restriction site variation}

Fragment pattern differences between the sibling species were detected in digests with $\mathrm{HpaII}$ for the 16S rRNA region, and HinfI, $C f o$ I and $M s p I$ for the COI-COII intergenic region. Only two patterns were identified: A and B. Each earwig was then characterized by a fourletter composite mtDNA genotype (the four letters denoting the fragment pattern observed, for HpaII, $M s p \mathrm{I}, C f o \mathrm{I}$ and HinfI, respectively). All individuals have either an AAAA (haplotype A) or a BBBB (haplotype B) composite genotype. These two distinct haplotypes correspond to the sibling species: the A haplotype characterizes the species making only one oviposition per year, and the B haplotype corresponds to the second species, which produces two clutches per year (Guillet et al. 2000).

\section{Geographical distribution of mtDNA genotypes}

Figure 1 illustrates the distribution of the two mitochondrial haplotypes along the elevation transect. Samples located at the lowest $(900-1100 \mathrm{~m})$ and the highest $(1300-1500 \mathrm{~m})$ altitudes were monomorphic, the B haplotype characterizing the lowest samples, whereas the A haplotype was found in the highest samples. By contrast, the intermediate sample $(1200 \mathrm{~m})$ was poly-

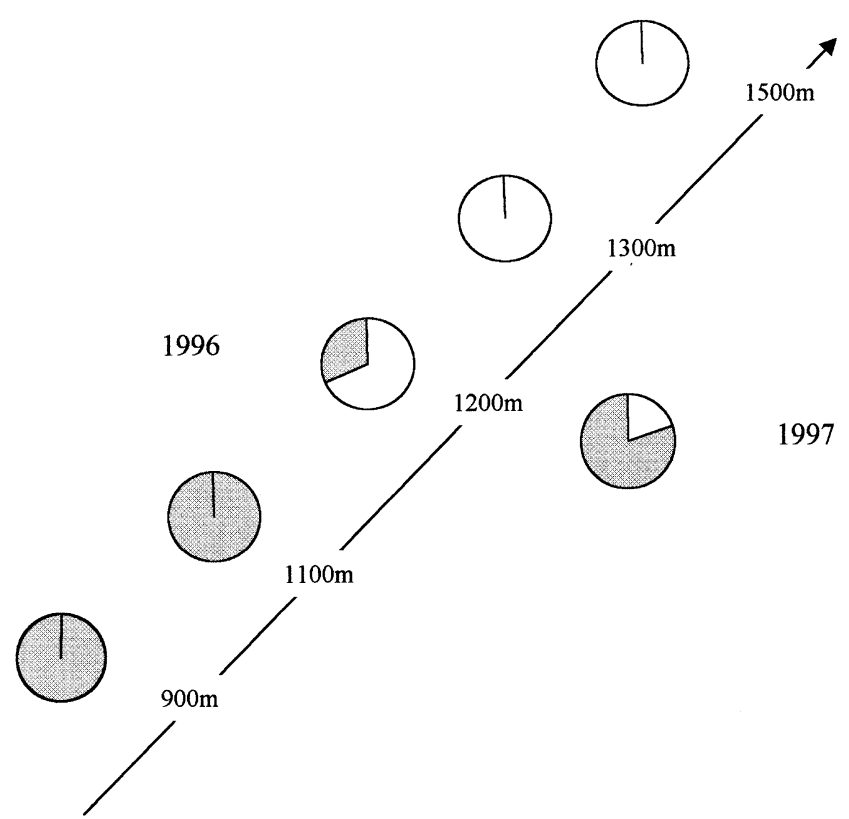

Fig. 1 Distribution of the two mitochondrial haplotypes along the elevation transect (in white haplotype A and in grey haplotype B). morphic with the A and B haplotypes in proportions $68 \%$ and $32 \%$, respectively. This haplotype mixing was confirmed the following year (1997). In a sample of 64 individuals, the two haplotypes were found again but in significantly different proportions (only $20 \%$ of haplotype A, $\left.\chi^{2}=14, P<0.001\right)$.

\section{Allozyme variation}

Of the 37 loci coding for proteins surveyed in this study, four were polymorphic: PGI1, AAT1, Est-P1 and Est-P2 (frequency of the common allele being less than 0.95). Two more loci (CAT and EST) were polymorphic but they were difficult to score consistently and were omitted from the analysis. The observed allele frequencies for the four loci are reported in Table 1. Great allelic variation was found according to altitude. Specimens collected at $1200 \mathrm{~m}$ were considered initially as a sample of a single population, but were subsequently reconsidered as a mixture of two populations (1200 mA and $1200 \mathrm{mB}$ ) differing in mitochondrial genotype. Only one 'diagnostic allele' was found: allele 1 at locus $A A T 1$ is only present in individuals of haplotype A, but is at a low frequency (mean 20\%). Other alleles are shared by the species, but large differences in frequencies are observed between samples, especially between interspecific samples.

\section{Genetic structure of populations}

Few significant departures in genotype distribution from the Hardy-Weinberg model were observed; however, large heterozygote deficiencies were observed at locus Est-P2 in samples of species B. This is certainly a result of the presence of a null allele because a lack of enzymatic activity was observed for six individuals. If this locus is excluded from analysis, $F_{\text {IS-values observed are no longer significant. Mean }}$ heterozygosities in the various populations showed marked variation among loci (from 0.074 for Est-P2 to 0.379 for $P G I 1$ ) and among demes (from 0.046 for $1300 \mathrm{~m}$ to 0.336 for $900 \mathrm{~m}$ ) (Table 1). The most variable samples are those of B mtDNA lineage, located up to $1200 \mathrm{~m}$.

The mean weighted $F_{\mathrm{ST}}$-values, summed across loci, obtained within each species separately, and between the two species, are presented in Table 2. Intraspecific $F_{\mathrm{ST}}$-values are low and not significant $(0.047$ for species A and 0.043 for species B), whereas mean $F_{\mathrm{ST}}$ reached 0.257 between the two species and is significantly greater than zero $(P<0.001)$. All loci are involved in the genetic differentiation between species (not shown) because statistically significant differences were found at all loci $(P<0.001)$. Substantial 
Table 1 Allele frequencies, observed $\left(H_{\mathrm{o}}\right)$ and expected $\left(H_{\mathrm{e}}\right)$ mean heterozygosities, significant deviations $(D)$ from Hardy-Weinberg expectations, and estimate $F_{\text {IS }}$ over loci for contact zone populations of Forficula auricularia

\begin{tabular}{|c|c|c|c|c|c|c|c|c|c|}
\hline \multirow[b]{2}{*}{ Locus } & \multirow[b]{2}{*}{ Sample } & \multicolumn{8}{|c|}{ Haplotype } \\
\hline & & $\begin{array}{c}\text { B } \\
900 \mathrm{~m}\end{array}$ & $\begin{array}{c}\text { B } \\
1100 \mathrm{~m}\end{array}$ & $\begin{array}{c}\text { B } \\
1200 \mathrm{mB}\end{array}$ & $\begin{array}{c}\mathrm{A} / \mathrm{B} \\
1200 \mathrm{~m}\end{array}$ & $\begin{array}{c}\mathrm{A} \\
1200 \mathrm{~mA}\end{array}$ & $\begin{array}{c}\text { A } \\
1300 \mathrm{~m}\end{array}$ & $\begin{array}{c}\text { A } \\
1500 \mathrm{~m}\end{array}$ & $\begin{array}{c}\text { Mean } \\
\text { (6 samples) }\end{array}$ \\
\hline Pgil & $N$ & 29 & 30 & 6 & 21 & 15 & 30 & 30 & \\
\hline \multirow[t]{7}{*}{ Freq. } & Allele 1 & 0.345 & 0.250 & 0.50 .0 & 0.143 & 0.000 & 0.033 & 0.117 & 0.179 \\
\hline & 2 & 0.448 & 0.650 & 0.417 & 0.833 & 1.000 & 0.950 & 0.783 & 0.729 \\
\hline & 3 & 0.190 & 0.083 & 0.083 & 0.024 & 0.000 & 0.000 & 0.017 & 0.064 \\
\hline & 4 & 0.000 & 0.000 & 0.000 & 0.000 & 0.000 & 0.017 & 0.083 & 0.021 \\
\hline & 5 & 0.017 & 0.000 & 0.000 & 0.000 & 0.000 & 0.000 & 0.000 & 0.007 \\
\hline & $H_{\mathrm{o}}$ & 0.655 & 0.567 & 0.833 & 0.238 & 0.000 & 0.033 & 0.367 & 0.379 \\
\hline & $\begin{array}{l}H_{\mathrm{e}} \\
D\end{array}$ & 0.644 & 0.474 & 0.569 & 0.285 & 0.000 & $\begin{array}{c}0.096 \\
D^{*}\end{array}$ & 0.366 & 0.377 \\
\hline Aat1 & $N$ & 29 & 30 & 6 & 20 & 14 & 18 & 25 & \\
\hline \multirow[t]{4}{*}{ Freq. } & 1 & 0.000 & 0.000 & 0.000 & 0.237 & 0.321 & 0.194 & 0.120 & 0.090 \\
\hline & 2 & 1.000 & 1.000 & 1.000 & 0.763 & 0.679 & 0.806 & 0.880 & 0.910 \\
\hline & $H_{\mathrm{o}}$ & 0 & 0 & 0 & 0.250 & 0.357 & 0.278 & 0.240 & 0.131 \\
\hline & $H_{\mathrm{e}}$ & 0 & 0 & 0 & 0.362 & 0.436 & 0.313 & 0.211 & 0.149 \\
\hline Est-P1 & $N$ & 28 & 29 & 7 & 22 & 15 & 30 & 30 & \\
\hline \multirow[t]{4}{*}{ Freq. } & 1 & 0.732 & 0.845 & 0.857 & 0.955 & 1.000 & 1.000 & 0.983 & 0.90 .3 \\
\hline & 2 & 0.268 & 0.155 & 0.143 & 0.045 & 0.000 & 0.000 & 0.017 & 0.097 \\
\hline & $H_{\mathrm{o}}$ & 0.464 & 0.241 & 0.286 & 0.091 & 0.000 & 0.000 & 0.033 & 0.165 \\
\hline & $H_{\mathrm{e}}$ & 0.392 & 0.262 & 0.245 & 0.086 & 0.000 & 0.000 & 0.033 & 0.154 \\
\hline Est-P2 & $N$ & 27 & 28 & 7 & 21 & 14 & 30 & 30 & \\
\hline \multirow[t]{8}{*}{ Freq. } & 1 & 0.259 & 0.537 & 0.286 & 0.119 & 0.000 & 0.000 & 0.017 & 0.178 \\
\hline & 2 & 0.741 & 0.463 & 0.714 & 0.881 & 1.000 & 1.000 & 0.983 & 0.822 \\
\hline & $H_{\mathrm{o}}$ & 0.222 & 0.111 & 0.000 & 0.000 & 0.000 & 0.000 & 0.033 & 0.0 .74 \\
\hline & $H_{\mathrm{e}}$ & 0.384 & 0.497 & 0.408 & 0.210 & 0.000 & 0.000 & 0.033 & 0.218 \\
\hline & $D$ & $D^{*}$ & $D^{* * *}$ & $D^{*}$ & $D^{* *}$ & & & & \\
\hline & $H_{\mathrm{o}}$ & 0.336 & 0.233 & 0.269 & 0.143 & 0.086 & 0.046 & 0.165 & 0.189 \\
\hline & $H_{\mathrm{e}}$ & 0.354 & 0.30 .4 & 0.307 & 0.232 & 0.10 .5 & 0.079 & 0.159 & 0.227 \\
\hline & $F_{\mathrm{IS}}$ & 0.069 & 0.272 & 0.208 & 0.372 & 0.217 & 0.320 & -0.025 & \\
\hline
\end{tabular}

$* P<0.05,{ }^{* *} P<0.01,{ }^{* * *} P<0.001$.

Table 2 Intraspecific and interspecific values of mean $F_{\mathrm{ST}}$ summed across loci (Weir \& Cockerham, 1984) for the sibling species of F.auricularia

\begin{tabular}{lll}
\hline Intraspecific & Species A & 0.047 \\
& Species B & 0.043 \\
Interspecific & Species A/Species B & $0.257^{* * *}$ \\
& $1200 \mathrm{~mA} /$ Species B & $0.256^{* * *}$ \\
& $1200 \mathrm{mB} /$ Species A & $0.296^{* * *}$ \\
\hline
\end{tabular}

$* * * P<0.001$.

variations in electromorph distribution were a consequence of predominant or fixed allelic differences between species.

Higher divergence is found between populations of different mtDNA lineage, meaning between sibling

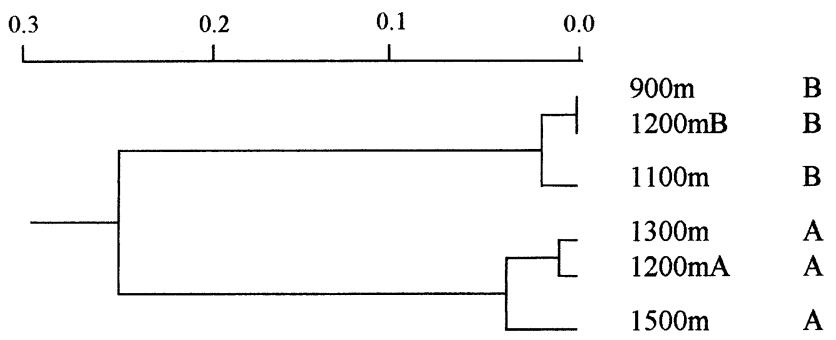

Fig. 2 UPGMA based on $F_{\mathrm{ST}}$-values obtained for the four enzymatic loci.

species. The UPGMA phenogram derived from pairwise $F_{\mathrm{ST}}$-values estimated between samples is given in Fig. 2. This phenogram illustrates the substantial divergences mentioned above, and it clearly clusters samples. The same dichotomy is obtained with $F_{\mathrm{ST}}$-values and with 
mitochondrial data because we observed two groups corresponding to the sibling species.

\section{Discussion}

The PCR-RFLP method is a rapid way of distinguishing the sibling species into two well-differentiated mitochondrial lineages. It has already been used with success in North American populations to identify the two recently introduced species of the European earwig (Guillet et al. 2000). Indeed, molecular data have confirmed the identification of the sibling species based on reproductive data such as the number of clutches per year.

The sibling species live in sympatry in the Pyrenean mountains. Although individuals of the two species have been observed in the same habitat at $1200 \mathrm{~m}$, their relative ratios seem to change from year to year. Earwigs were trapped in a glade opened recently, about 30 years ago, so the coexistence clearly results from a secondary contact. The dynamics of this contact zone have been followed since 1996 in order (i) to determine if an equilibrium will be reached between the two species, or if one species will become established to the detriment of the other, and (ii) to evaluate the relative fitness of the two reproductive strategies (A and B) in this particular ecological context.

Sympatry raises the possibility of hybridization, even if this has never been observed in the laboratory by pairing individuals of the two species. In the laboratory, individuals mate, fertilization occurs, eggs can develop but never hatch, meaning that a postzygotic barrier may exist (Wirth et al., 1998). Because of its maternal inheritance, mitochondrial data cannot by themselves confirm the lack of hybridization, even if no mitochondrial introgression has been observed in this study.

For allozymic data, samples that are monomorphic for mitochondrial haplotype can be considered as references of the pure parental types. Few fixed allelic differences have been found, but samples do show large variations in allelic frequencies. Populations higher than $1200 \mathrm{~m}$ appeared less variable, possible as a consequence of isolation by altitude or because they represent a potential refugium.

Originally, allelic frequencies observed at $1200 \mathrm{~m}$ seemed intermediate compared to those observed in the reference populations. But after dividing this sample in two subpopulations, according to the mitochondrial genotype of individuals, the new allelic frequencies observed are comparable with those observed in the parental populations (Table 1). This result is consistent with a lack of nuclear introgression.

On the UPGMA phenogram based on $F_{\mathrm{ST}}$-values, population clustering occurred according to the mitochondrial haplotypes and did not reveal an intermediate nuclear genotype. Within each species, $F_{\mathrm{ST}}$ values were low ( 0.047 within species $A$ and 0.043 within species B), whereas between the sibling species $F_{\mathrm{ST}}$ reached 0.257 and was significantly greater than zero $(P<0.001)$. Furthermore, when either the $1200 \mathrm{~mA}$ or the $1200 \mathrm{mB}$ samples is compared to samples from the other species, the $F_{\mathrm{ST}}$-value obtained (respectively 0.256 or $0.296, P<0.001)$ is comparable to the mean $F_{\mathrm{ST}}$ $(0.257)$ observed globally between species (Table 2 ). In the case of hybridization, these $F_{\mathrm{ST}^{-}}$-values would have been lower, revealing the presence of introgression. Allozyme data did not show significant exchange in nature, presumably as a result of reproductive isolation barriers. A comparable study was carried out on Anopheles pseudopunctipennis (Estrada-Franco et al., 1993), where variation in allozymes and ribosomal DNA (RFLP) revealed a complex of sibling species with limited or no interspecific gene flow. Within each species, $F_{\mathrm{ST}}$-values were low (0.035 and 0.039$)$, whereas $F_{\mathrm{ST}}$-coefficients reached 0.468 between species.

Although only few allozymic loci and few individuals were used in our study, the different markers do show concordant genetic partition that agrees with the reproductive boundaries revealed through experimental crosses. Indeed, introgression implies not only hybridization but viability and fertility of hybrids. Such a phenomenon has never been observed in the laboratory. The two species of earwig appear to represent genetic entities that coexist in a narrow contact zone.

\section{Acknowledgements}

We thank Zaffreen Pinay for reading the manuscript, Estelle Prelli and Maud Gourden for scoring allozymic loci, and the two anonymous referees for their constructive comments on the manuscript.

\section{References}

ARNOLD, M. L. 1992. Natural hybridization as an evolutionary process. Ann. Rev. Ecol. Syst., 23, 237-261.

AVISE, J. C. 1994. Molecular Markers, Natural History and Evolution. Chapman \& Hall, New York.

AVISE, J. C. AND SAUNDERS, N. C. 1984. Hybridization and introgression among species of sunfish (genus Lepomis): analysis by mitochondrial DNA and allozyme markers. Genetics, 108, 237-255.

BAKER, R. J., DAVIS, S. K., BRADLEY, R. D., HAMILTON, M. J. AND VAN DEN BUSSCHE, R. A. 1989. Ribosomal DNA, mitochondrial DNA, chromosomal, and allozymic studies on a contact zone in the pocket gopher. Geomys. Evolution, 43, 63-75.

BARTON, N. H. AND HEWITT, G. M. 1985. Analysis of hybrid zones. Ann. Rev. Ecol. Syst., 16, 113-148. 
BARTON, N. H. AND HEWITT, G. M. 1989. Adaptation, speciation and hybrid zones. Nature, 341, 497-503.

BEALL, G. 1932. The life history and behaviour of the European earwig, Forficula auricularia, in British Columbia. Proc. Ent. Soc. B. C., 39, 28-43.

BERT, T. M. AND HARRISON, R. G. 1988. Hybridization in western atlantic stone crabs (genus Menippe): Evolutionary history and ecological context influence species interactions. Evolution, 42, 528-544.

ESTRADA-FRANCO, J. G., LANZARO, G. C., MA, M. C., WALKERABBey, A., ROMANS, P., GALVAN-SANChEZ, C. ET $A L .1993$. Characterization of Anopheles pseudopunctipennis sensu lato from three countries of neotropical America from variation in allozymes and ribosomal DNA. Am. J. Trop. Med. Hyg., 49 (6), 735-745.

FERris, S. D., SAGE, R. D., HUANG, C. M., NIELSEN, J. T., RITTE, U. AND WILSON, A. C. 1983. Flow of mitochondrial DNA across a species boundary. Proc. Natl. Acad. Sci. U.S.A., 80, 2290-2294.

GOUDET, J. 1995. FSTAT, Version 1-2: a computer program to calculate F-statistics. J. Hered., 86, 485-486.

Guillet, S., JosSELIN, N. AND VANCASSEl, M. 2000. Multiple introductions of Forficula auricularia L. species complex (Dermaptera: Forficulidae) in eastern North America. Can. Ent., 132, 49-57.

HARRISON, R. G. 1993. Hybrid Zones and the Evolutionary Process. Oxford University Press, New York.

HARRISON, R. G., RAND, D. M. AND WHEELER, W. C. 1987. Mitochondrial DNA variation in field crickets across a narrow hybrid zone. Mol. Biol. Evol., 4, 144-158.

HEwITT, G. M. 1993. After the ice: Parallelus meets erythropus in the Pyrenees. In: Harrison, R. G. (ed.) Hybrid Zones and the Evolutionary Process, pp. 140-163. Oxford University Press, New York.

LAMB, R. J. AND Wellington, w. G. 1974. Techniques for studying the behavior and ecology of European earwig Forficula auricularia. Can. Ent., 106, 881-888.

LAMB, R. J. AND WELlington, w. G. 1975. Life history and population characteristics of the European earwig, Forficula auricularia (Dermaptera: Forficulidae), at Vancouver, British Columbia. Can. Ent., 107, 819-824.

Lehman, N., EISENhaWer, A., HANSEN, K., MeCH, L. D., PeTERSON, R. O., GOGAN, P. J. P. ET AL. 1991. Introgression of coyote mitochondrial DNA into sympatric north american gray wolf populations. Evolution, 45, 104-119.

MARCHANT, A. D. 1988. Apparent introgression of mitochondrial DNA across a narrow hybrid zone in the Caledia captiva species-complex. Heredity, 60, 39-46.

NELSON, K., BAKER, R. J. AND HONEYCUTT, R. L. 1987. Mitochondrial DNA and protein differentiation between hybridizing cytotypes of the white-footed mouse, Peromyscus leucopus. Evolution, 41, 864-872.
OLDROYD, B. P., CORNUET, J. M., ROWE, D., RINDERER, T. E. AND CROZIER, R. H. 1995. Racial admixture of Apis mellifera in Tasmania, Australia: similarities and differences with natural hybrid zones in Europe. Heredity, 74, 315-325.

RAND, D. M. AND HARRISON, R. G. 1989. Ecological genetics of a mosaic hybrid zone: mitochondrial, nuclear, and reproductive differentiation of crickets by soil type. Evolution, 43, 432-449.

RAYMOND, M. AND ROUSSET, F. 1995. GENEPOP (Version 1.2): a population genetics software for exact tests and ecumenicism. J. Hered., 86, 248-249.

RIESEBERG, L. H. 1998. Molecular Ecology of Hybridization. Adv. Mol. Ecol., 306, 243-265.

SAMBRoOK, J., FRITSCH, E. F. AND MANIATIS, T. 1989. Molecular Cloning: a Laboratory Manual. Cold Spring Harbor Laboratory Press, NY.

SECOND, G. AND TROUSLOT, P. 1980. Electrophorèse d'enzymes de riz: technique d'électrophorèse en gel d'amidon appliquée à l'étude du polymorphisme de quatorze enzymes de riz. Trav. Doc. L'orstom, 20, 88p.

SPOLSKY, C. AND UZZELL, T. 1984. Natural interspecies transfer of mitochondrial DNA in amphibians. Proc. Natl. Acad. Sci. U.S.A., 81, 5802-5805.

SWOFFORD, D. L. AND SELANDER, R. B. 1989. BIOSYS-1. A computer program for the analysis of allelic variation in population genetics and biochemical systematics. Release 1.7. University of Illinois, Urbana, IL.

SZYMURA, J. M. AND BARTON, N. H. 1991. The genetic structure of the hybrid zone between the fire-bellied toads Bombina bombina and B.varietaga: comparisons between transects and between loci. Evolution, 45, 237-261.

VANCASSEL, M. 1984. Plasticity and adaptative radiation of Dermapteran parental behavior: results and perspectives. Adv. Stud. Behav., 14, 51-80.

VASQuez, P., COOPER, S. J. B., GOSAlvez, J. AND HEWITT, G. M. 1994. Nuclear DNA introgression across a Pyrenean hybrid zone between parapatric subspecies of the grasshopper Chorthippus parallelus. Heredity, 73, 436-443.

WEIR, B. S. AND COCKERHAM, C. C. 1984. Estimating F-statistics for the analysis of population structure. Evolution, 38, 1358-1370.

WEYRAUCH, W. K. 1929. Experimentelle analyse der Brutpflege des Ohrwürmes Forficula auricularia. L. Biol. Zbl., 49, 543-558.

WIRTH, T., LE GUELleC, R., VANCASSEL, M. AND VEUILle, M. 1998. Molecular and reproductive characterization of sibling species in the European earwig (Forficula auricularia). Evolution, 52, 260-265.

WRIGHT, S. 1965. The interpretation of population structure by F-statistics with special regard to systems of mating. Evolution, 19, 395-420. 